For resubmission to Water Research (Manuscript ID WR-S-14-0465)

\title{
Rapid and successful start-up of anammox process by immobilizing the minimal quantity of biomass in PVA-SA gel beads
}

\author{
By
}

Muhammad Ali ${ }^{\mathrm{a}}$, Mamoru Oshiki ${ }^{\mathrm{b}}$, Lashitha Rathnayake ${ }^{\mathrm{a}}$, Satoshi Ishii ${ }^{\mathrm{a}}$, Hisashi Satoh $^{\mathrm{a}}$, and Satoshi Okabe $\mathrm{a}^{\mathrm{a}, *}$

\section{Category: Original reserch paper}

${ }^{a}$ Division of Environmental Engineering, Faculty of Engineering, Hokkaido University, North 13, West-8, Sapporo, Hokkaido 060-8628, Japan.

${ }^{b}$ Department of Civil Engineering, Nagaoka National College of Technology, 888 Nishikatakaimachi, Nagaoka, Niigata 940-0834, Japan.

${ }^{*}$ Corresponding author: Satoshi Okabe, North 13, West-8, Sapporo, Hokkaido 060-8628, Phone \& Fax: +81-(0)11-706-6266,E-mail: sokabe@eng.hokudai.ac.jp. 


\section{ABSTRACT}

Rapid start-up of anaerobic ammonium oxidation (anammox) process in up-flow column reactors was successfully achieved by immobilizing minimal quantity of biomass in polyvinyl alcohol (PVA)-sodium alginate (SA) gel beads. The changes in the reactor performance (i.e., nitrogen removal rate; NRR) were monitored with time. The results demonstrate that the reactor containing the immobilized biomass concentration of $0.33 \mathrm{~g}-\mathrm{VSS} \mathrm{L}{ }^{-1}$ achieved NRR of $10.8 \mathrm{~kg}-\mathrm{N} \mathrm{m}^{-3} \mathrm{~d}^{-1}$ after

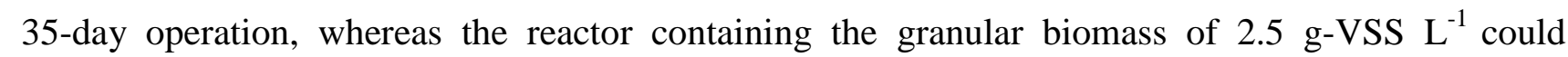
achieve only NRR of $3.5 \mathrm{~kg}-\mathrm{N} \mathrm{m}^{-3} \mathrm{~d}^{-1}$. This indicates that the gel immobilization method requires much lower seeding biomass for start-up of anammox reactor. To explain the better performance of the immobilized biomass, the biological and physicochemical properties of the immobilized biomass were characterized and compared with the naturally aggregated granular biomass. Effective diffusion coefficient $\left(D_{e}\right)$ in the immobilized biomass was directly determined by microelectrodes and found to be three times higher than one in the granular biomass. High anammox activity (i.e., $\mathrm{NH}_{4}{ }^{+}$and $\mathrm{NO}_{2}{ }^{-}$ consumption rates) was evenly detected throughout the gel beads by microelectrodes due to faster and deeper substrate transport. In contrast, anammox activity was localized in the outer layers of the granular biomass, indicating that the inner biomass could not contribute to the nitrogen removal. This difference was in good agreement with the spatial distribution of microbes analysed by fluorescence in situ hybridization (FISH). Based on these results, PVA-SA gel immobilization is an efficient strategy to initiate anammox reactors with minimal quantity of anammox biomass.

Keywords: anaerobic ammonium oxidation; startup of anammox process; gel immobilization; effective diffusion coefficient 


\section{INTRODUCTION}

Anaerobic ammonium oxidation (anammox) process has been regarded as an efficient, cost

effective and environmental friendly alternative to conventional nitrogen removal process due to lower oxygen demand, no external carbon source requirement, lower sludge production and less $\mathrm{N}_{2} \mathrm{O}$ gas emission (Kartal et al., 2010; Kuenen, 2008; Okabe et al., 2011). Anammox process has been installed for various wastewaters treatment, and there are presently more than 100 full-scale anammox plants around the world (Lackner et al., 2014). One of the remaining important challenges in practical application of anammox process is slow and unstable start-up due to their slow growth van der Star et al., 2007). To further promote the full-scale anammox installations, it is required to establish a more rapid and reliable start-up method. For rapid and successful start-up of anammox process, a sufficient amount of seeding biomass is essential, and the inoculated biomass must be efficiently retained in the reactor. Biomass washout due to production of $\mathrm{N}_{2}$ gas bubbles was another cause of the failure of process start-up (Chen et al., 2010; Dapena-Mora et al., 2004).

In order to secure enough seeding biomass, the preservation of anammox biomass could be one of possible solutions (Ali et al., 2014b; Heylen et al., 2012; Rothrock et al., 2011; Vlaeminck et al., 2007). Ali et al. (2014b) recently reported that anammox biomass could be stored for five months at room temperature in nutrient medium containing $3 \mathrm{mM}$ molybdate with periodical supplementation of $\mathrm{NH}_{4}^{+}$and $\mathrm{NO}_{2}^{-}$. However there is a limitation of biomass storage capacity in practice. It is therefore desirable to determine the necessary minimal quantity of anammox biomass for successful start-up.

In order to efficiently retain the inoculated biomass in a reactor, biomass could be immobilized in gel beads, which allows us to operate the reactor at high nitrogen loading rates (i.e., at short hydraulic retention time) without nitrite inhibition and biomass washout (Isaka et al., 2006; Magrí et al., 2012; Vogelsang et al., 1999). This reactor operation is suitable for cultivation of anammox 
bacteria (Tsushima et al., 2007a). Anammox bacteria were successfully immobilized either in polyvinyl alcohol (PVA) (Magrí et al., 2012), sodium alginate (SA) (Zhu et al. 2009), mixture of PVA and SA (Ali et al., 2014b; Quan et al., 2011), or polyethylene glycol (PEG) (Isaka et al., 2011), and the reactors consisting of these immobilized gel beads could achieve the nitrogen removal rates (NRRs) of $0.58 \sim 12 \mathrm{~kg}-\mathrm{N} \mathrm{m}^{-3} \mathrm{~d}^{-1}$ within time periods of $35 \sim 180$ days. In these studies, the initial biomass concentrations were varied; 1.8 g-volatile suspended solids (VSS) (L of reactor volume) ${ }^{-1}$ (Magrí et al., 2012), 3.5 g-VSS L ${ }^{-1}$ (Zhu et al., 2009), 5 g-SS L ${ }^{-1}$ (Quan et al., 2011), and 5.2 g-VSS $\mathrm{L}^{-1}$ (Isaka et al., 2011). Although the minimal biomass concentration, that is necessary for successful start-up of anammox process, has not been studied and reported so far. The minimal biomass concentration must be experimentally determined to reduce the required seeding biomass. In addition, a detailed comparison of biological and physicochemical properties between naturally aggregated granular and artificially immobilized anammox biomass has not been characterized in the previous studies.

The objective of this study was, therefore, to determine the minimal concentration of anammox biomass immobilized in gel beads that is necessary for rapid and successful start-up of anammox process. The criteria of the rapid and successful start-up of anammox reactor in this study was defined as follows; an acceptable start-up time period of anammox reactors is about a month and a target volumetric nitrogen removal rate is $10 \mathrm{~kg}-\mathrm{N} \mathrm{m} \mathrm{m}^{-3}$ because the first full-scale anammox reactor in Rotterdam, NL has been operated at around $7 \mathrm{~kg}-\mathrm{N} \mathrm{m}^{-3} \mathrm{~d}^{-1}$ (Lackner et al., 2014; van der Star et al., 2007) and some pilot- and lab-scale experiments using similar immobilized biomass were conducted at around $10 \mathrm{~kg}-\mathrm{N} \mathrm{m}^{-3} \mathrm{~d}^{-1}$ (Ali et al., 2014; Quan et al., 2011). The minimal concentration of anammox biomass that is necessary for meeting these criteria was determined in this study. For this purpose, different amounts of anammox biomass were immobilized in a mixture gel of PVA and SA, and the immobilized gels were packed in up-flow column reactors. The influence of the initial biomass concentration on the start-up and performance of anammox process were investigated and 
compared with the reactor containing the naturally aggregated granular biomass. Furthermore, the detailed comparison of biological and physicochemical properties such as effective diffusion coefficient and anammox activity in the immobilized gel beads and granules was made on the basis of various in situ analyses: fluorescence in situ hybridization (FISH) analysis, microelectrode measurements, and ${ }^{13} \mathrm{C}$-bicarbonate incorporation analysis by secondary ion mass spectrometry (SIMS).

\section{MATERIALS AND METHODS}

\subsection{Anammox biomass}

Naturally aggregated granular anammox biomass (average 5-mm of diameter) (hereafter referred as granular biomass), was harvested from an up-flow anammox reactor (hereafter referred as parent reactor) (Tsushima et al., 2007b) (Fig. 1A). The granular biomass contains mono species of anammox bacterium, "Candidatus Brocadia sinica", and they accounted for more than $94 \%$ of total bacterial cells as determined by FISH (Oshiki et al., 2011).

\subsection{Biomass immobilization}

Granular biomass was dispersed by a mortar-pestle style tissue homogenizer $\left(50 \mathrm{~cm}^{3}, \Phi 6 \times 290 \times\right.$ $195 \mathrm{~mm})$ into small floccular biomass $(<100 \mu \mathrm{m}$ diameter) and diluted with culture medium (described below in section 2.3) to six different biomass concentrations i.e. 4.8, 4.1, 3.3, 2.3, 0.9 and $0.5 \mathrm{~g}$-VSS L ${ }^{-1}$. Autoclaved immobilization support solutions of $6 \%(\mathrm{w} / \mathrm{v})$ PVA and $2 \%(\mathrm{w} / \mathrm{v}) \mathrm{SA}$ were mixed with an equal volume of the prepared biomass suspension as described previously (Ali et al., 2014b). The mixture was dropped into a solution of $4 \%(\mathrm{w} / \mathrm{v}) \mathrm{CaCl}_{2}$ by using a peristaltic pump (Eyela Roller Pump RP, Tokyo, Japan) equipped with a PharMed BPT tube (ID $3.1 \mathrm{~mm}$ ), forming spherical gel beads with 4 5-mm diameter (Fig. 1B). The immobilized gel beads were cured in the same $\mathrm{CaCl}_{2}$ solution for $12 \mathrm{~h}$ to enhance their mechanical stability. The immobilized anammox biomass (hereafter referred as immobilized biomass) were collected and rinsed thrice with deionized 
water and inoculated in up-flow column reactors.

\subsection{Reactor establishment and operation}

Immobilized biomass with different initial biomass concentrations were separately inoculated into six up-flow glass column reactors $(10-\mathrm{mL}, \Phi 18 \times 80 \mathrm{~mm}$, FujiRika, Osaka, Japan) with a packing ratio of $70 \%(\mathrm{v} / \mathrm{v})$ (Fig. 1C). Anammox biomass concentrations in the reactors were 1.67, $1.45,1.15,0.82,0.33$ and $0.16 \mathrm{~g}$-VSS L $\mathrm{L}^{-1}$ (" $\mathrm{L}^{-1 \text { " }}$ here and hereafter referred to the volume of the reactor) in reactor 1 to 6 , respectively (Table S1). Likewise, granular biomass $(\Phi 4 \sim 5 \mathrm{~mm})$ was harvested from the parent reactor and transferred to the same 10-ml glass column reactor with a packing ratio of $30 \%$ that corresponds to the biomass concentration of $2.5 \mathrm{~g}-\mathrm{VSS} \mathrm{L}^{-1}$ (Fig. 1D). These column reactors were fed with synthetic medium and operated for 35 days at $37^{\circ} \mathrm{C}$. The synthetic medium used in the present study contained; $\mathrm{NH}_{4}^{+}(2.5 \sim 7.5) \mathrm{mM}, \mathrm{NO}_{2}^{-}(2.5 \sim 7.5) \mathrm{mM}$, $\mathrm{CaCl}_{2} 100 \mathrm{mg} \mathrm{L}^{-1}, \mathrm{MgSO}_{4} 300 \mathrm{mg} \mathrm{L}{ }^{-1}, \mathrm{KH}_{2} \mathrm{PO}_{4} 30 \mathrm{mg} \mathrm{L}^{-1}, \mathrm{KHCO}_{3} 500 \mathrm{mg} \mathrm{L}^{-1}$ and trace element solution (van de Graaf et al., 1995). Concentrations of $\mathrm{NH}_{4}{ }^{+}$and $\mathrm{NO}_{2}{ }^{-}$were set at $2.5 \mathrm{mM}$ for $0 \sim 14$ days, and increased to 5.0 and $7.5 \mathrm{mM}$ after 15- and 30-day operation, which resulted in nitrogen loading rates (NLRs) of 4.3, 8.1 and $12.1 \mathrm{~kg}-\mathrm{N} \mathrm{m}^{-3} \mathrm{~d}^{-1}$, respectively (Table S1). Hydraulic retention time (HRT) was set at $0.42 \mathrm{~h}$. Concentrations of $\mathrm{NH}_{4}{ }^{+}, \mathrm{NO}_{2}{ }^{-}$and $\mathrm{NO}_{3}{ }^{-}$in the influent and effluent of the reactors during operation were determined using ion chromatographs (IC-2010, TOSOH, Tokyo, Japan) equipped with TSKgel IC-Anion HS and TSKgel IC-Cation columns (TOSOH) after filtration using 0.45- $\mu \mathrm{m}$-pore-size membranes (Okabe et al., 2011).

\subsection{Specific anammox activity}

Specific anammox activity (SAA) was determined by measuring ${ }^{29} \mathrm{~N}_{2}$ production rate as previously described (Ali et al., 2014b; Oshiki et al., 2013). Briefly, granular and immobilized biomass were suspended into the anammox culture medium (without $\mathrm{NH}_{4}{ }^{+}$and $\mathrm{NO}_{2}{ }^{-}$), and then $5 \mathrm{ml}$ of each biomass suspension was dispensed into serum vials $(12.5 \mathrm{ml}$, Nichiden-Rika Glass, Kobe, Japan) separately and sealed with butyl rubber stoppers and aluminium caps. To avoid oxygen 
contamination, all biomass was handled in an anaerobic chamber (Coy Laboratory Products, Grass Lake Charter Township, MI, USA), and the headspace gas was exchanged with ultra-pure He gas (>99.9999\%) by using a gas exchange machine (model IP-8, SANSHIN, Yokohama, Japan). The vials were pre-incubated at $37^{\circ} \mathrm{C}$ for at least $6 \mathrm{hr}$, and then ${ }^{15} \mathrm{~N}-\mathrm{NH}_{4} \mathrm{Cl}$ and ${ }^{14} \mathrm{~N}-\mathrm{NaNO}_{2}$ were supplemented to each vial at a final concentration of $2.5 \mathrm{mM}$ each and incubated at $37^{\circ} \mathrm{C}$. Fifty microliter of headspace gas was collected after every hour by a gas tight syringe (VICI, Baton Rouge, LA, USA) and injected to a gas chromatograph (GCMS-QP2010SE, Shimadzu, Japan) equipped with a CP-Pora Bond Q fused silica capillary column (Agilent Technologies, Santa Clara, CA, USA), and $\mathrm{m} / \mathrm{z}=28,29$ and 30 were monitored. Concentrations of ${ }^{28} \mathrm{~N}_{2},{ }^{29} \mathrm{~N}_{2}$ and ${ }^{30} \mathrm{~N}_{2}$ gas were determined by gas chromatography mass spectrometry analysis (Amano et al., 2007; Waki et al., 2010). Specific ammonium oxidation rate was determined by measuring ${ }^{29} \mathrm{~N}_{2}$ gas production rate. Amount of ${ }^{29} \mathrm{~N}_{2}$ gas was quantified by a standard curve prepared with ${ }^{30} \mathrm{~N}_{2}$ standard gas (>98\% purity, Cambridge Isotope Laboratories, Tewksbury, MA, USA) (Oshiki et al., 2013). This experiment was performed in triplicate for each type of biomass. Biomass concentration was determined as protein concentration and converted to g-VSS $\mathrm{L}^{-1}$ as previously described (Oshiki et al., 2011). Briefly, biomass was pelleted by centrifugation (18,200 $g$ for $10 \mathrm{~min})$, and the biomass pellet was suspended in $10 \%(\mathrm{w} / \mathrm{v})$ sodium dodecyl sulfate solution. After boiling for $10 \mathrm{~min}$, the suspension was centrifuged at $18,200 \mathrm{~g}$ for $10 \mathrm{~min}$. Protein concentration in the supernatant was determined by Lowry method (Lowry et al., 1951) using DC Protein Assay Kit (Bio-Rad) as described in the manufacture instruction.

\subsection{FISH analysis}

Granular biomass and immobilized biomass (harvested from reactor 3) were fixed with $4 \%$ (w/v) paraformaldehyde in phosphate-buffer saline (PBS; 10mM sodium phosphate buffer, $130 \mathrm{mM}$ sodium chloride; $\mathrm{pH} 7.2$ ) at $4^{\circ} \mathrm{C}$ for $6 \mathrm{hr}$. Biomass was then washed thrice with PBS and embedded in Tissue-Tek optimal cutting temperature (OCT) compound (Sakura Finetek, Torrance, CA) at $-30^{\circ} \mathrm{C}$. Thin sections (20 $\mu \mathrm{m}$ in thickness) of biomass were prepared using a cryostat (Reichert-Jung Cryout 
1800, Leica, Bensheim, Germany) and pasted on teflon coated glass slides. FISH was performed using the probes EUB mix (FITC) and AMX 820 (TRITC) as described previously (Okabe et al., 1999b) to identify total and anammox bacterial population, respectively. Hybridized samples were observed using confocal laser-scanning microscope (TCS SP8, Leica, Japan) equipped with Ar ion and He-Ne laser. Later, obtained microscopic images were processed and analysed by Leica Application Suite Advanced Fluorescence, (LAS AF, version 4.4).

\subsection{Microelectrode measurements}

The steady state concentration micro-profiles of $\mathrm{NH}_{4}{ }^{+}, \mathrm{NO}_{2}{ }^{-}, \mathrm{NO}_{3}{ }^{-}$and $\mathrm{pH}$ in granular and immobilized biomass were measured using liquid ion exchanger (LIX) type microelectrodes (de Beer et al., 1997a). The microelectrodes were prepared, calibrated, and operated as previously described (Okabe et al., 1999a; Rathnayake et al., 2013; Satoh et al., 2007). The synthetic medium used for microelectrode measurements was of same composition as described in section 2.3. The granular and immobilized biomass (harvested from reactor 3) were incubated in a flow chamber (2.5 L) containing anoxic medium for at least $3 \mathrm{~h}$ before microelectrode measurements to ensure that steady-state profiles were obtained. Microelectrodes were inserted almost perpendicular to the surface of the biomass. The liquid-biofilm interface was identified by a high precision stereo microscope (Stemi 2000, Carl Zeiss, Germany). Temperature of the anoxic medium was maintained at $37^{\circ} \mathrm{C}$ throughout the experiments. At least three profiles were measured for each chemical species using different aggregate as previously described (Song et al., 2013).

\subsection{Effective diffusion coefficient}

Effective diffusion coefficients of the granular and immobilized biomass were directly measured by using LIX-type $\mathrm{NH}_{4}{ }^{+}$specific microelectrode as suggested previously (Stewart, 2003). Briefly, the granular and immobilized biomass were washed thrice with deionized water before measurements. Both the granular and immobilized biomass were incubated in a small flow chamber (300-mL volume) filled with $100 \mathrm{~mL}$ of medium containing $1 \mathrm{mM} \mathrm{NH}_{4}^{+}$(without $\mathrm{NO}_{2}{ }^{-}$and $\mathrm{NO}_{3}{ }^{-}$). 
175 An ammonium specific microelectrode was inserted perpendicular to the respective biomass at 500 $\mu \mathrm{m}$ depth from the surface. At steady microelectrode reading, $10 \mathrm{~mL}$ of $100 \mathrm{mM} \mathrm{NH}_{4}^{+}$solution was added to increase $\mathrm{NH}_{4}{ }^{+}$concentration of bulk solution to $10 \mathrm{mM}$. The steady reading was defined as the point at which fluctuation in reading for 20 seconds became lower than $0.1 \mathrm{mV}$. The time was recorded to attain the reading corresponding to $90 \%$ of bulk solution concentration $\left(9 \mathrm{mM} \mathrm{NH}_{4}^{+}\right)$. Strict anoxic condition was maintained by purging $\mathrm{N}_{2}$ gas to avoid oxidation of $\mathrm{NH}_{4}^{+}$by nitrifiers. Three measurements were recorded for each type of biomass. Effective diffusion coefficients were calculated by using the following equation:

$$
D_{e}=0.37 \times d^{2} / t_{90 \%}
$$

Where, $D_{e}$ is effective diffusion coefficient in the biomass, $d$ is the penetration depth and $t_{90 \%}$ is the time required for the solute to attain $90 \%$ of the bulk solution concentration at the penetration depth $d$. The values of $\left(D_{a q}\right)$, diffusion coefficients in pure water for $\mathrm{NH}_{4}{ }^{+}, \mathrm{NO}_{2}{ }^{-}$and $\mathrm{NO}_{3}{ }^{-}$, were taken from literature (Yi et al., 2011). The relative effective diffusivity, described as a ratio $D_{e} / D_{a q}$, was determined for $\mathrm{NH}_{4}{ }^{+}$. Same relative effective diffusivity was used to determine effective diffusion coefficient for $\mathrm{NO}_{2}{ }^{-}$and $\mathrm{NO}_{3}{ }^{-}$. Furthermore, volumetric $\mathrm{NH}_{4}{ }^{+}$and $\mathrm{NO}_{2}{ }^{-}$consumption and $\mathrm{NO}_{3}{ }^{-}$production rates were estimated from the respective solute concentration profiles by using the Fick's second law of diffusion as described previously (Lorenzen et al., 1998; Nakamura et al., 2004). Following equation (Eq. 2), derived from the Fick's second law of diffusion, was used to simulate concentration profiles on the basis of volumetric $\mathrm{NH}_{4}{ }^{+}$and $\mathrm{NO}_{2}{ }^{-}$consumption and $\mathrm{NO}_{3}{ }^{-}$production rates, $\left(A_{n} \times D_{e}\right)$. The derivation and terms used in this equation was previously explained elsewhere (Lorenzen et al., 1998).

$$
C_{n+1}=C_{n}+h \times\left[\partial C / \partial z_{n-1}+h \times A_{n-1}\right]
$$

\subsection{Isotope microscopic analysis}

Granular and immobilized biomass were separately inoculated in up-flow column reactors and operated under the same operating conditions as previously mentioned in section 2.3. Biomass 
200 concentrations in the granular and immobilized biomass reactors were 1.15 and $2.5 \mathrm{~g} \mathrm{VSS} \mathrm{L}^{-1}$, 201 respectively. These reactors were continuously fed with ${ }^{13} \mathrm{C}-\mathrm{NaHCO}_{3}(97 \%$ chemical purity, 202 Cambridge Isotope Laboratories, MA, USA) as a sole carbon source. After 35-day operation, 203 granular and immobilized biomass were harvested and washed thrice with phosphate buffered saline 204 solution. Washed biomass were embedded in Tissue-Tek OCT compound and sectioned into slices 205 (10 $\mu \mathrm{m}$ in thickness) by using a cryostat (Reichert-Jung Cryout 1800, Leica, Bensheim, Germany). 206 These thin sections were pasted on silica wafers. An in situ survey of spatial distribution of $207{ }^{13} \mathrm{C}$-carbon incorporation by anammox bacterial cells in the granular and immobilized biomass was 208 performed by line profiling analysis using a secondary ion mass spectrometry SIMS (ims-1270, 209 CAMECA, France) equipped with an ion detector (stacked CMOS-type active pixel sensor; 210 SCAPS)(Sakamoto et al., 2007).

\section{RESULTS AND DISCUSSIONS}

\subsection{Influence of initial biomass content on start-up of anammox process}

Six up-flow column reactors packed with the immobilized anammox biomass (containing biomass concentrations of $0.16 \sim 1.67 \mathrm{~g}$-VSS $\mathrm{L}^{-1}$ ) were operated for 35 days at $37^{\circ} \mathrm{C}$. As for 216 comparison, a column reactor containing the granular biomass of $2.5 \mathrm{~g}$-VSS L${ }^{-1}$ was also operated under the same conditions. Nitrogen loading rates were increased when the effluent $\mathrm{NO}_{2}{ }^{-}$ concentrations in all reactors except for reactor 6 became below $15 \mathrm{mg} \mathrm{L}^{-1}$ to avoid nitrite inhibition (Fig. S1). NRRs increased with time in all the reactors (Fig. 2). Stoichiometric ratios of consumed $\mathrm{NO}_{2}{ }^{-}$to consumed $\mathrm{NH}_{4}{ }^{+}\left(\Delta \mathrm{NO}_{2}{ }^{-} / \Delta \mathrm{NH}_{4}{ }^{+}\right)$and produced $\mathrm{NO}_{3}{ }^{-}$to consumed $\mathrm{NH}_{4}{ }^{+}\left(\Delta \mathrm{NO}_{3}{ }^{-} / \Delta \mathrm{NH}_{4}{ }^{+}\right)$in the reactors were in the range of 1.1 1.4 and 0.16 0.22, respectively. Those stoichiometric ratios are close to the theoretical stoichiometric ratios of anammox reaction (i.e. 1.15 and 0.16 for $\Delta \mathrm{NO}_{2}{ }^{-} / \Delta \mathrm{NH}_{4}{ }^{+}$and $\Delta \mathrm{NO}_{3}{ }^{-} / \Delta \mathrm{NH}_{4}{ }^{+}$, respectively) (Lotti et al., 2014), indicating anammox was responsible for nitrogen removal in these reactors. During the operation of the column reactors, the 
color of the immobilized biomass was changed from pale white to reddish color, indicating the growth of anammox bacteria (Fig. 1E). For initial few days, NRRs were dependent on the initial biomass content: the higher initial biomass concentrations resulted in higher NRRs (Fig. 2). The

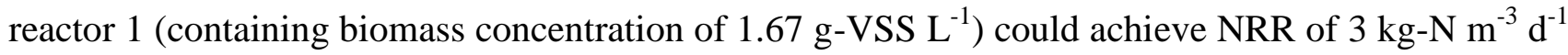
just after 7-day operation, whereas the NRR of the reactor 5 (containing $0.33 \mathrm{~g}$-VSS L ${ }^{-1}$ ) was about $50 \%$ of the reactor 1 . However, the difference in NRR gradually became small as time passed.

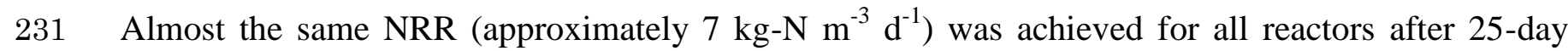
232 operation and then reached above $10 \mathrm{~kg}-\mathrm{N} \mathrm{m}^{-3} \mathrm{~d}^{-1}$ after 33 days, except for the reactor 6 (containing 233 the lowest biomass concentration of $0.16 \mathrm{~g}-\mathrm{VSS} \mathrm{L}^{-1}$ ) and granular biomass reactor (containing 2.5 $234 \mathrm{~g}-\mathrm{VSS} \mathrm{L}^{-1}$ ). The NRR of the reactor 6 was slowly but steadily increased to $5.8 \mathrm{~kg}-\mathrm{N} \mathrm{m}^{-3} \mathrm{~d}^{-1}$, whereas 235 the granular biomass reactor could attain only NRR of $3.5 \mathrm{~kg}-\mathrm{N} \mathrm{m}^{-3} \mathrm{~d}^{-1}$ at the end of operation. Based on these experimental results, the minimal concentration of anammox biomass that is necessary for meeting the criteria of rapid and successful start-up of anammox process was $0.33 \mathrm{~g}-\mathrm{VSS} \mathrm{L}^{-1}$ in this study. It should be noted that the granular reactor containing the highest biomass $\left(2.5 \mathrm{~g}-\mathrm{VSS} \mathrm{L}^{-1}\right)$

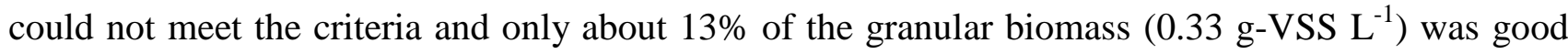
enough to achieve rapid and successful start-up when the biomass is immobilized in PVA-SA gel 241 beads.

\subsection{Specific anammox activity of immobilized biomass}

To explain the better performance of the immobilized biomass reactor, specific anammox activity (SAA) was determined after 35-day operation by measuring the production of mixed labelled ${ }^{14+15} \mathrm{~N}_{2}$ from the cultures incubated with ${ }^{15} \mathrm{~N}$-ammonium and ${ }^{14} \mathrm{~N}$-nitrite. Reactor 3 was chosen as a representative of immobilized anammox biomass due to its stable reactor performance. The specific anammox activity (SAA) was measured only for the biomass harvested from the reactor 3 and 
distinguished from the heterotrophic denitrification and other biological reactions (Holtappels et al.,

251 2011; Kartal et al., 2007). The SAA of the immobilized biomass was $278.5 \pm 30.9 \mu$ mol- ${ }^{29} \mathrm{~N}_{2} \mathrm{~g}-\mathrm{VSS}^{-1}$ $252 \mathrm{~h}^{-1}$, which was significantly higher than that of the granular biomass $\left(184.7 \pm 30.9 \mu \mathrm{mol}-{ }^{29} \mathrm{~N}_{2} \mathrm{~g}-\mathrm{VSS}^{-1}\right.$ $\left.253 \mathrm{~h}^{-1}\right)(\mathrm{P}<0.05)($ Table 1). These values were within the range of previously determined SAA values for 254 anammox biomass (Dapena-Mora et al., 2007; Isaka et al., 2008; Magrí et al., 2012). The higher 255 SAA of the immobilized biomass supported the higher NRRs of the immobilized biomass reactors 256 with lower biomass concentration.

$257 \quad$ 3.3. Effective diffusion coefficient in immobilized biomass

258 The effective diffusion coefficients, $D_{e}$, in the immobilized and granular biomass were 259 determined to explain the higher SAA in the immobilized biomass. Just like the SAA measurement, 260 the gel beads harvested from the reactor 3 was subjected to this measurement due to its stable reactor 261 performance. It is speculated that $D_{e}$ in the immobilized biomass is different from that in the granular 262 biomass because $D_{e}$ is highly dependent on the biomass matrix such as gel polymer or bacterial 263 biomass including microbial exoplymers (de Beer et al., 1997b; Stoodley et al., 1994; Stewart, 1998). 264 The $D_{e}$ of $\mathrm{NH}_{4}{ }^{+}$at $37^{\circ} \mathrm{C}$ in the granular and immobilized biomass were determined to be $2658.6 \pm 2.3 \times 10^{-6} \mathrm{~cm}^{2} \mathrm{~s}^{-1}$ and $29.0 \pm 6.7 \times 10^{-6} \mathrm{~cm}^{2} \mathrm{~s}^{-1}$, respectively (Table 2). Accordingly, the ratios of $266 D_{e} / D_{a q}$ were calculated as 0.23 and 0.77 , respectively. These values of $D_{e} / D_{a q}$ were comparable to the 267 values for biofilms (Stewart, 2003). The determined $D_{e}$ values were used for the following 268 calculation of volumetric $\mathrm{NH}_{4}{ }^{+}$and $\mathrm{NO}_{2}{ }^{+}$consumption rates and $\mathrm{NO}_{3}{ }^{-}$production rate on the basis of 269 concentration profiles determined by microelectrode measurements (Fig. 3).

$270 \quad 3.4$ Spatial distribution and activity of anammox bacteria

In order to explain the higher SAA in the immobilized biomass than the granular biomass,

272 the spatial distributions of anammox activity and bacteria within the immobilized and granular 273 biomass were analyzed using microelectrode measurement and FISH analysis. The steady state 274 concentration profiles of $\mathrm{NH}_{4}{ }^{+}, \mathrm{NO}_{2}{ }^{-}, \mathrm{NO}_{3}{ }^{-}$, and $\mathrm{pH}$ in the granular and immobilized biomass were 
measured up to a depth of $1100 \mu \mathrm{m}$ with $100 \mu \mathrm{m}$ step size (Fig. 3A and B). The $\mathrm{NH}_{4}{ }^{+}$and $\mathrm{NO}_{2}{ }^{-}$ concentrations concomitantly decreased while the concentration of $\mathrm{NO}_{3}{ }^{-}$and $\mathrm{pH}$ increased inside the granular and immobilized biomass, which indicates typical evidence of anammox activity.

In the granular biomass, high $\mathrm{NH}_{4}{ }^{+}$and $\mathrm{NO}_{2}{ }^{+}$consumption rates were observed only in the outer $600 \mu \mathrm{m}$ (Fig. 3C). Even though $\mathrm{NH}_{4}{ }^{+}$and $\mathrm{NO}_{2}{ }^{-}$concentrations still remained at high levels, no significant anammox activity was observed below $600 \mu \mathrm{m}$ depth. This is probably because $\mathrm{pH}$ was increased up to 8.5 and higher in the inner layer (below $600 \mu \mathrm{m}$ ), which probably inhibited the anammox activity. It was reported that anammox activity was reduced to half (Awata et al., 2013; Oshiki et al., 2011) and even to quarter (Ali et al., 2014a) at pH 8.5. Similar localizations of anammox activity, $\mathrm{NH}_{4}{ }^{+}$and $\mathrm{NO}_{2}{ }^{-}$consumptions, $\mathrm{NO}_{3}{ }^{-}$production and increase in $\mathrm{pH}$ mainly in the outer $0 \sim 500 \mu \mathrm{m}$ layer, were observed in the anammox biofilms (Cho et al., 2011; Kindaichi et al., 2007; Tsushima et al., 2007a).

In contrast, moderate $\mathrm{NH}_{4}{ }^{+}$and $\mathrm{NO}_{2}{ }^{-}$consumption and $\mathrm{NO}_{3}{ }^{-}$production rates were evenly observed throughout the immobilized biomass (down to $1,100 \mu \mathrm{m}$ ) (Fig. 3D). $\mathrm{pH}$ around 7.6 7.8 was unchanged throughout the immobilized biomass. These experimental data suggested that substrates and bicarbonate were rapidly replenished from the bulk solution since the effective diffusion coefficient in the immobilized biomass was three times higher than one in the granular biomass (Table 2). To our knowledge this is the first report presenting experimental evidence to explain the high anammox activity in the immobilized biomass.

Substrate transport limitation due to the low diffusivity in the granular biomass resulted in the localization of anammox activity (Fig. 3A and 3C) and consequently bacterial cells (biomass) in the outer layer (Fig. 4 and Fig. S2). Similar localizations of bacterial cells or biomass density in the anammox granules and biofilms were reported previously (Kindaichi et al., 2007; Lin et al., 2013; Tsushima et al., 2007b). High biomass density and low effective diffusion of substrates created the sharp decrease in $\mathrm{NH}_{4}{ }^{+}$and $\mathrm{NO}_{2}{ }^{+}$concentrations and $\mathrm{pH}$ increase in the granular biomass (Fig. 3A). 
300 Anammox biomass in the inner part of the granule biomass did not contribute to the overall nitrogen removal. In contrast, due to the higher diffusivity the substrate transport was accelerated to sustain the activity of anammox bacteria throughout the immobilized biomass, which leads to the homogeneous distribution of anammox biomass (Fig. 4B and Fig. S2) and consequently the higher SAA than the granular biomass (Table 1). It should be noted that biomass concentration is important for the immobilized biomass reactors whereas specific surface area is more important than biomass concentration for the granular biomass reactor due to substrate transport limitation.

\section{5. $\quad{ }^{13} \mathrm{C}$-bicarbonate incorporation}

The spatial distributions of in situ anammox activity of the immobilized and granular biomass were further investigated by measuring ${ }^{13} \mathrm{C}$-bicarbonate incorporation of anammox bacterial cells by using a secondary ion mass spectrometry (SIMS) (Fig. 5). Much higher incorporation of

${ }^{13} \mathrm{C}$-bicarbonate was observed in the immobilized biomass than the granular biomass. Anammox bacteria present even in the inner part of the immobilized biomass significantly incorporated ${ }^{13} \mathrm{C}$-bicarbonate, but not in the granular biomass. Adsorption and entrapment of ${ }^{13} \mathrm{C}$-bicarbonate in gel matrix was not observed for the immobilized gel beads incubated as negative control. These results were in good agreement with the results of the microelectrode measurements and FISH analysis.

For this experiment, selection of isotope-labelled substrate and incubation time were important to avoid cross-feeding of isotope (Kindaichi et al., 2004; Okabe et al., 2005).

${ }^{13} \mathrm{C}$-bicarbonate was used as a labelling substrate (carbon source) in this study, because anammox bacteria dominated in both the biomass (more than $94 \%$ of total bacteria) and all reactors were operated under anoxic condition to exclude the contribution of ammonium-oxidizing bacteria (AOB).

322 Considering the doubling time and growth yield of $\mathrm{Ca}$. Brocadia sinica (Oshiki et al., 2011) and preliminary experimental results, 35-day incubation period was chosen, in which the ${ }^{13} \mathrm{C}$ cross-feed to heterotrophic bacteria likely did not occur. 


\section{4. CONCLUSION}

- For rapid and successful start-up of anammox process, anammox biomass was immobilized in a mixture gel of $6 \%(\mathrm{w} / \mathrm{v})$ PVA and $2 \%(\mathrm{w} / \mathrm{v}) \mathrm{SA}$, which were then packed in up-flow column reactors. The minimal initial concentration of anammox biomass that is necessary for meeting the criterion of rapid and successful start-up (achieving the nitrogen removal rate (NRR) of higher than $10 \mathrm{~kg}-\mathrm{N} \mathrm{m}^{-3} \mathrm{~d}^{-1}$ within a month) was determined.

- The column reactor containing the immobilized biomass $\left(0.33 \mathrm{~g}\right.$-VSS $\left.\mathrm{L}^{-1}\right)$ was started up much faster than the reactor containing the granular biomass $\left(2.5 \mathrm{~g}-\mathrm{VSS} \mathrm{L}^{-1}\right)$ and achieved higher NRR (10.8 $\left.\mathrm{kg}-\mathrm{N} \mathrm{m}^{-3} \mathrm{~d}^{-1}\right)$ after 35-day operation. This result indicates that PVA-SA gel immobilization is an efficient strategy to initiate anammox reactors with minimal quantity of anammox biomass.

- The effective diffusion coefficient in the immobilized biomass (gel beads) was directly determined by microelectrodes and found to be more than three times higher than one in the naturally aggregated granular biomass. The substrate transport was accelerated to sustain the activity of anammox bacteria in the inner part of the immobilized biomass, which consequently resulted in the higher nitrogen removal rate than the granular biomass.

A considerably small amount of anammox biomass is enough for successful establishment of anammox reactors if PVA-SA gel immobilization technology is used. It often needs long periods of time and many efforts to grow anammox granules. Even though granules were developed, anammox biomass inside of the granules would not contribute to nitrogen removal due to diffusion limitation as presented in this study. Although the gel immobilization is an efficient method to establish anammox reactors, the hydrodynamic behaviour and durability of the immobilized biomass for long-term operation should be investigated at pilot-scale in future study. Furthermore, this gel immobilization technology should be tested for mixed AOB and anammox populations for a single-stage nitritation/anammox process to promote practical application in wastewater treatment. 

353 CREST, Nagase Science and Technology Foundation, and Institute for Fermentation, Osaka (IFO), 354 which were granted to S. Okabe. Muhammad Ali expresses his utmost gratitude to the Ministry of 355 Education, Culture, Sports, Science and Technology (MEXT), Government of Japan for providing 356 doctoral scholarship. 


\section{REFERENCES}

Ali, M., Oshiki, M., Awata, T., Isobe, K., Kimura, Z., Yoshikawa, H., Hira, D., Kindaichi, T., Satoh, H., Fujii, T., Okabe, S., 2014a. Physiological characterization of anaerobic ammonium oxidizing bacterium “Candidatus Jettenia caeni.” Environ. Microbiol. In press. doi:10.1111/1462-2920.12674

Ali, M., Oshiki, M., Okabe, S., 2014b. Simple, rapid and effective preservation and reactivation of anaerobic ammonium oxidizing bacterium "Candidatus Brocadia sinica.” Water Res 57, $215-222$.

Amano, T., Yoshinaga, I., Okada, K., Yamagishi, T., Ueda, S., Obuchi, A., Sako, Y., Suwa, Y., 2007. Detection of anammox activity and diversity of anammox bacteria-related 16S rRNA genes in coastal marine sediment in Japan. Microbes Env. 22, 232-242.

Awata, T., Oshiki, M., Kindaichi, T., Ozaki, N., Ohashi, A., Okabe, S., 2013. Physiological characterization of an anaerobic ammonium-oxidizing bacterium belonging to the "Candidatus Scalindua” group. Appl Env. Microb 79, 4145-4148.

Chen, J., Ji, Q., Zheng, P., Chen, T., Wang, C., Mahmood, Q., 2010. Floatation and control of granular sludge in a high-rate anammox reactor. Water Res. 44, 3321-3328.

Cho, S., Fujii, N., Lee, T., Okabe, S., 2011. Development of a simultaneous partial nitrification and anaerobic ammonia oxidation process in a single reactor. Bioresour. Technol. 102, 652-659.

Dapena-Mora, A., Campos, J.L., Mosquera-Corral, A., Jetten, M.S.M., Mendez, R., 2004. Stability of the ANAMMOX process in a gas-lift reactor and a SBR. J. Biotechnol. 110, 159-170.

Dapena-Mora, A., Fernández, I., Campos, J.L.L., Mosquera-Corral, A., Méndez, R., Jetten, M.S.M.S.M., Fernandez, I., Mendez, R., 2007. Evaluation of activity and inhibition effects on Anammox process by batch tests based on the nitrogen gas production. Enzym. Microb Tech 40, 859-865.

de Beer, D., Schramm, A., Santegoeds, C.M., Kuhl, M., 1997a. A nitrite microsensor for profiling environmental biofilms. Appl Env. Microb 63, 973-977.

de Beer, D., Stoodley, P., Lewandowski, Z., 1997b. Measurement of local diffusion coefficients in biofilms by microinjection and confocal microscopy. Biotechnol. Bioeng. 53, 151-158. 
Heylen, K., Ettwig, K., Hu, Z.Y., Jetten, M., Kartal, B., 2012. Rapid and simple cryopreservation of anaerobic ammonium-oxidizing bacteria. Appl Env. Microb 78, 3010-3013.

Holtappels, M., Lavik, G., Jensen, M.M., Kuypers, M.M.M., 2011. Chapter ten - 15N-Labeling Experiments to Dissect the Contributions of Heterotrophic Denitrification and Anammox to Nitrogen Removal in the OMZ Waters of the Ocean, in: Martin, G.K. (Ed.), Methods in Enzymology. Academic Press, pp. 223-251.

Isaka, K., Date, Y., Kimura, Y., Sumino, T., Tsuneda, S., 2008. Nitrogen removal performance using anaerobic ammonium oxidation at low temperatures. FEMS Microbiol Lett 282, 32-38.

Isaka, K., Date, Y., Sumino, T., Yoshie, S., Tsuneda, S., 2006. Growth characteristic of anaerobic ammonium-oxidizing bacteria in an anaerobic biological filtrated reactor. Appl Microbiol Biot $70,47-52$.

Isaka, K., Itokawa, H., Kimura, Y., Noto, K., Murakami, T., 2011. Novel autotrophic nitrogen removal system using gel entrapment technology. Bioresour. Technol. 102, 7720-7726.

Jetten, M.S.M., Strous, M., van de Pas-Schoonen, K.T., Schalk, J., van Dongen, U.G.J.M., van de Graaf, A.A., Logemann, S., Muyzer, G., van Loosdrecht, M.C.M., Kuenen, J.G., 1999. The anaerobic oxidation of ammonium. FEMS Microbiol Rev 22, 421-437.

Kartal, B., Kuenen, J.G., van Loosdrecht, M.C.M., 2010. Sewage treatment with anammox. Science 328, 702-703.

Kartal, B., Kuypers, M.M.M., Lavik, G., Schalk, J., Op den Camp, H.J.M., Jetten, M.S.M., Strous, M., den Camp, H.J.M.O., 2007. Anammox bacteria disguised as denitrifiers: nitrate reduction to dinitrogen gas via nitrite and ammonium. Env. Microbiol 9, 635-642.

Kindaichi, T., Ito, T., Okabe, S., 2004. Ecophysiological interaction between nitrifying bacteria and heterotrophic bacteria in autotrophic nitrifying biofilms as determined by microautoradiography-fluorescence in situ Hybridization. Appl Env. Microb 70, 1641-1650.

Kindaichi, T., Tsushima, I., Ogasawara, Y., Shimokawa, M., Ozaki, N., Satoh, H., Okabe, S., 2007. In situ activity and spatial organization of anaerobic ammonium-oxidizing (anammox) bacteria in biofilms. Appl Env. Microb 73, 4931-4939.

Kuenen, J.G., 2008. Anammox bacteria: from discovery to application. Nat. Rev. Microbiol. 6, $320-326$. 
Lackner, S., Gilbert, E.M., Vlaeminck, S.E., Joss, A., Horn, H., van Loosdrecht, M.C.M., 2014. Full-scale partial nitritation/anammox experiences--an application survey. Water Res. 55, 292-303.

Lin, Y.M., Lotti, T., Sharma, P.K., van Loosdrecht, M.C.M., 2013. Apatite accumulation enhances the mechanical property of anammox granules. Water Res. 47, 4556-66.

Lorenzen, J., Larsen, L.H., Kjaer, T., Revsbech, N., 1998. Biosensor determination of the microscale distribution of nitrate, nitrate assimilation, nitrification, and denitrification in a diatom-inhabited freshwater sediment. Appl Env. Microb 64, 3264-3269.

Lotti, T., Kleerebezem, R., Lubello, C., van Loosdrecht, M.C.M., 2014. Physiological and kinetic characterization of a suspended cell anammox culture. Water Res. 60, 1-14.

Lowry, O.H., Rosebrough, N.J., Farr, A.L., Randall, R.J., 1951. Protein measurement with the folin phenol reagent. J. Biol. Chem. 193, 265-275.

Magrí, A., Vanotti, M.B., Szögi, A. a, 2012. Anammox sludge immobilized in polyvinyl alcohol (PVA) cryogel carriers. Bioresour. Technol. 114, 231-40.

Nakamura, Y., Satoh, H., Okabe, S., Watanabe, Y., 2004. Photosynthesis in sediments determined at high spatial resolution by the use of microelectrodes. Water Res 38, 2440-2448.

Okabe, S., Itoh, T., Satoh, H., Watanabe, Y., 1999a. Analyses of spatial distributions of sulfate-reducing bacteria and their activity in aerobic wastewater biofilms. Appl Env. Microb 65, 5107-5116.

Okabe, S., Kindaichi, T., Ito, T., 2005. Fate of ${ }^{14} \mathrm{C}$-labeled microbial products derived from nitrifying bacteria in autotrophic nitrifying biofilms. Appl Env. Microb 71, 3987-3994.

Okabe, S., Oshiki, M., Takahashi, Y., Satoh, H., 2011. $\mathrm{N}_{2} \mathrm{O}$ emission from a partial nitrification-anammox process and identification of a key biological process of $\mathrm{N}_{2} \mathrm{O}$ emission from anammox granules. Water Res 45, 6461-6470.

Okabe, S., Satoh, H., Watanabe, Y., 1999b. In situ analysis of nitrifying biofilms as determined by in situ hybridization and the use of microelectrodes. Appl Env. Microb 65, 3182-3191.

Oshiki, M., Ishii, S., Yoshida, K., Fujii, N., Ishiguro, M., Satoh, H., Okabe, S., 2013. Nitrate-dependent ferrous iron oxidation by anaerobic ammonium oxidation (Anammox) bacteria. Appl Env. Microb 79, 4087-4093. 
Oshiki, M., Shimokawa, M., Fujii, N., Satoh, H., Okabe, S., 2011. Physiological characteristics of the anaerobic ammonium-oxidizing bacterium “Candidatus Brocadia sinica.” Microbiology 157, 1706-1713.

Park, H., Rosenthal, A., Ramalingam, K., Fillos, J., Chandran, K., 2010. Linking community profiles, gene expression and $\mathrm{N}$-removal in anammox bioreactors treating municipal anaerobic digestion reject water. Environ. Sci. Technol. 44, 6110-6116.

Quan, L.M., Khanh, D.P., Hira, D., Fujii, T., Furukawa, K., 2011. Reject water treatment by improvement of whole cell anammox entrapment using polyvinyl alcohol/alginate gel. Biodegradation 22, 1155-1167.

Rathnayake, R.M.L.D., Song, Y., Tumendelger, A., Oshiki, M., Ishii, S., Satoh, H., Toyoda, S., Yoshida, N., Okabe, S., 2013. Source identification of nitrous oxide on autotrophic partial nitrification in a granular sludge reactor. Water Res. 47, 7078-7086.

Rothrock, M.J., Vanotti, M.B., Szögi, A. a, Gonzalez, M.C.G., Fujii, T., Rothrock Jr., M.J., Szoegi, A.A., Garcia Gonzalez, M.C., 2011. Long-term preservation of anammox bacteria. Appl Microbiol Biot 92, 147-157.

Sakamoto, N., Seto, Y., Itoh, S., Kuramoto, K., Fujino, K., Nagashima, K., Krot, A.N., Yurimoto, H., 2007. Remnants of the early solar system water enriched in heavy oxygen isotopes. Science 317 , 231-233.

Satoh, H., Miura, Y., Tsushima, I., Okabe, S., 2007. Layered structure of bacterial and archaeal communities and their in situ activities in anaerobic granules. Appl. Environ. Microbiol. 73, 7300-7307.

Song, Y., Ishii, S., Rathnayake, L., Ito, T., Satoh, H., Okabe, S., 2013. Development and characterization of the partial nitrification aerobic granules in a sequencing batch airlift reactor. Bioresour. Technol. 139, 285-291.

Stewart, P.S., 1998. A review of experimental measurements of effective diffusive permeabilities and effective diffusion coefficients in biofilms. Biotechnol. Bioeng. 59, 261-72.

Stewart, P.S., 2003. Diffusion in Biofilms. J Bacteriol 185, 1485-1491.

Stoodley, P., de Beer, D., Lewandowski, Z., 1994. Liquid flow in biofilm systems. Appl Env. Microb $60,2711-2716$. 
Tsushima, I., Kindaichi, T., Okabe, S., 2007a. Quantification of anaerobic ammonium-oxidizing bacteria in enrichment cultures by real-time PCR. Water Res 41, 785-794.

Tsushima, I., Ogasawara, Y., Kindaichi, T., Satoh, H., Okabe, S., 2007b. Development of high-rate anaerobic ammonium-oxidizing (anammox) biofilm reactors. Water Res. 41, 1623-1634.

van de Graaf, A.A., Mulder, A., Bruijn, P. De, Jetten, M.S., Robertson, L.A., Kuenen, J.G., 1995. Anaerobic oxidation of ammonium is a biologically mediated process. Appl Env. Microb 61, $1246-1251$.

van der Star, W.R.L., Abma, W.R., Blommers, D., Mulder, J.-W., Tokutomi, T., Strous, M., Picioreanu, C., Van Loosdrecht, M.C.M., 2007. Startup of reactors for anoxic ammonium oxidation: Experiences from the first full-scale anammox reactor in Rotterdam. Water Res 41, 4149-4163.

Vlaeminck, S.E., Geets, J., Vervaeren, H., Boon, N., Verstraete, W., 2007. Reactivation of aerobic and anaerobic ammonium oxidizers in OLAND biomass after long-term storage. Appl Microbiol Biot 74, 1376-1384.

Vogelsang, C., Gollembiewski, K., Ostgaard, K., 1999. Effect of preservation techniques on the regeneration of gel entrapped nitrifying sludge. Water Res. 33, 164-168.

Waki, M., Yasuda, T., Suzuki, K., Sakai, T., Suzuki, N., Suzuki, R., Matsuba, K., Yokoyama, H., Ogino, A., Tanaka, Y., Ueda, S., Takeuchi, M., Yamagishi, T., Suwa, Y., 2010. Rate determination and distribution of anammox activity in activated sludge treating swine wastewater. Bioresour. Technol 101, 2685-2690.

Yi, Y., Yong, H., HuiPing, D., 2011. Effect of salt on anammox process. Procedia Environ. Sci. 10, 2036-2041.

Zhu, G.L., Hu, Y.Y., Wang, Q.R., 2009. Nitrogen removal performance of anaerobic ammonia oxidation co-culture immobilized in different gel carriers. Water Sci. Technol. 59, 2379-2386. 
499 Table 1: Specific anammox activity (SAA) of granular and immobilized biomass harvested from 500 up-flow column after 35 days of operation. Anammox activity was measured based on ${ }^{29} \mathrm{~N}-\mathrm{N}_{2}$ 501 production rate from ${ }^{15} \mathrm{~N}$-ammonium and ${ }^{14} \mathrm{~N}$-nitrite.

\begin{tabular}{|c|c|c|c|}
\hline \multicolumn{2}{|c|}{ Description } & Granular Biomass & Immobilized Biomass \\
\hline \multirow{2}{*}{$\begin{array}{c}{ }^{29} \mathrm{~N}_{2} \text { Production rate } \\
\left(\mu \text { mole }^{-1} \text { vial }^{-1}\right)\end{array}$} & AVG & 0.23 & 0.27 \\
\hline & SD & 0.03 & 0.03 \\
\hline \multirow{2}{*}{ Biomass concentration $^{3}$} & mg-protein vial ${ }^{-1}$ & 0.74 & 0.59 \\
\hline & mg-VSS vial ${ }^{-1}$ & 1.22 & 0.97 \\
\hline \multirow{6}{*}{$\begin{array}{l}\text { Specific anammox activity } \\
\left(\mu \text { mole }-{ }^{29} \mathrm{~N}_{2} \mathrm{~g}-\mathrm{VSS}^{-1} \mathrm{~h}^{-1}\right)\end{array}$} & AVG & 184.73 & 278.48 \\
\hline & $\mathrm{SD}$ & 30.92 & 30.94 \\
\hline & $n^{l}$ & 3 & 3 \\
\hline & $t$ & \multicolumn{2}{|c|}{-3.71} \\
\hline & $d f^{2}$ & \multicolumn{2}{|c|}{4} \\
\hline & p-value & \multicolumn{2}{|c|}{0.020} \\
\hline
\end{tabular}

5032 " $d f$ " represents degree of freedom.

$504{ }^{3}$ Conversion of protein concentration to VSS concentration was performed with a conversion factor of 1.64. 
Table 2: Effective diffusion coefficients, $D_{e}$, and relative effective diffusivity, $D_{e} / D_{a q}$, for granular 508 and immobilized biomass.

\begin{tabular}{|c|c|c|}
\hline \multirow[t]{2}{*}{ Description } & \multicolumn{2}{|c|}{$\begin{array}{l}\text { Effective diffusion coefficient, } \boldsymbol{D}_{\boldsymbol{e}} \\
\qquad\left(\times 10^{-6} \mathrm{~cm}^{2} \mathrm{~s}^{-1}\right)\end{array}$} \\
\hline & Granular biomass & Immobilized biomass \\
\hline $\mathrm{NH}_{4}^{+}$ & 8.61 & 28.99 \\
\hline $\mathrm{NO}_{2}^{-}$ & 8.31 & 27.96 \\
\hline \multirow[t]{2}{*}{$\mathrm{NO}_{3}^{-}$} & 8.26 & 27.82 \\
\hline & \multicolumn{2}{|c|}{ Relative effective diffusivity } \\
\hline$D_{e} / D_{a q}{ }^{1}$ & 0.23 & 0.77 \\
\hline
\end{tabular}

1 " $D_{e} / D_{a q}$ " indicates relative effective diffusivity and has no units. 

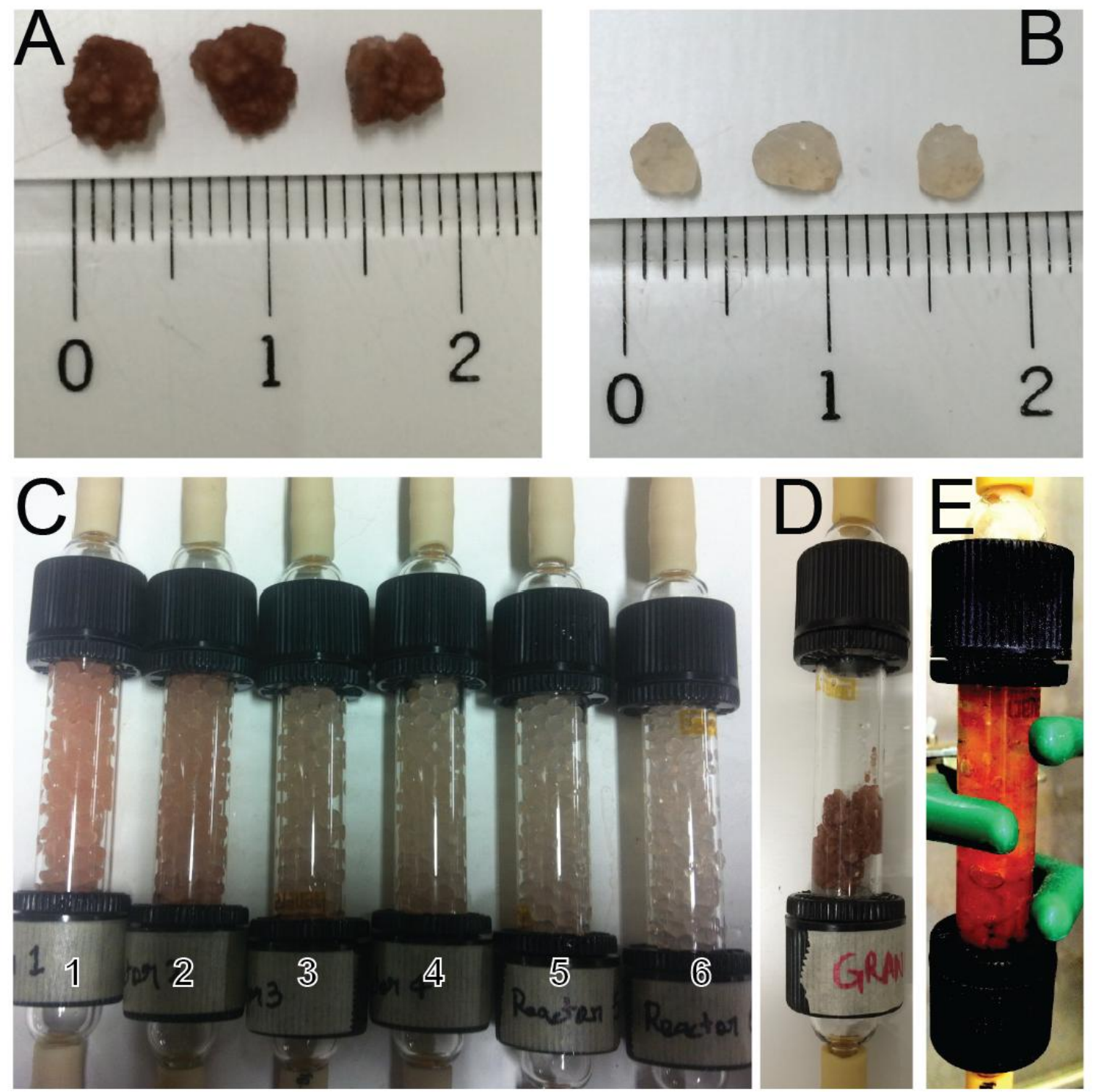

513 Fig. 1. A) Naturally grown granular biomass (diameter $4 \sim 5 \mathrm{~mm}$ ) harvested from a parent anammox 514 reactor (Tsushima et al., 2007b). B) The homogenized anammox biomass were immobilized in 515 PVA-SA gel beads (PVA $6 \%$ w/v, SA $2 \%$ w/v, diameter 4 5 mm). C) Up-flow column reactors 516 packed with the gel beads immobilized different initial biomass concentrations at the beginning of operation. More reddish gel beads indicate higher anammox biomass content. D) Up-flow column reactor packed with the naturally aggregated granular biomass at the start of operation. E) The up-flow column reactor after several days of operation. The gel beads exhibited vivid red color, indicating anammox bacteria have grown actively in the reactor. 


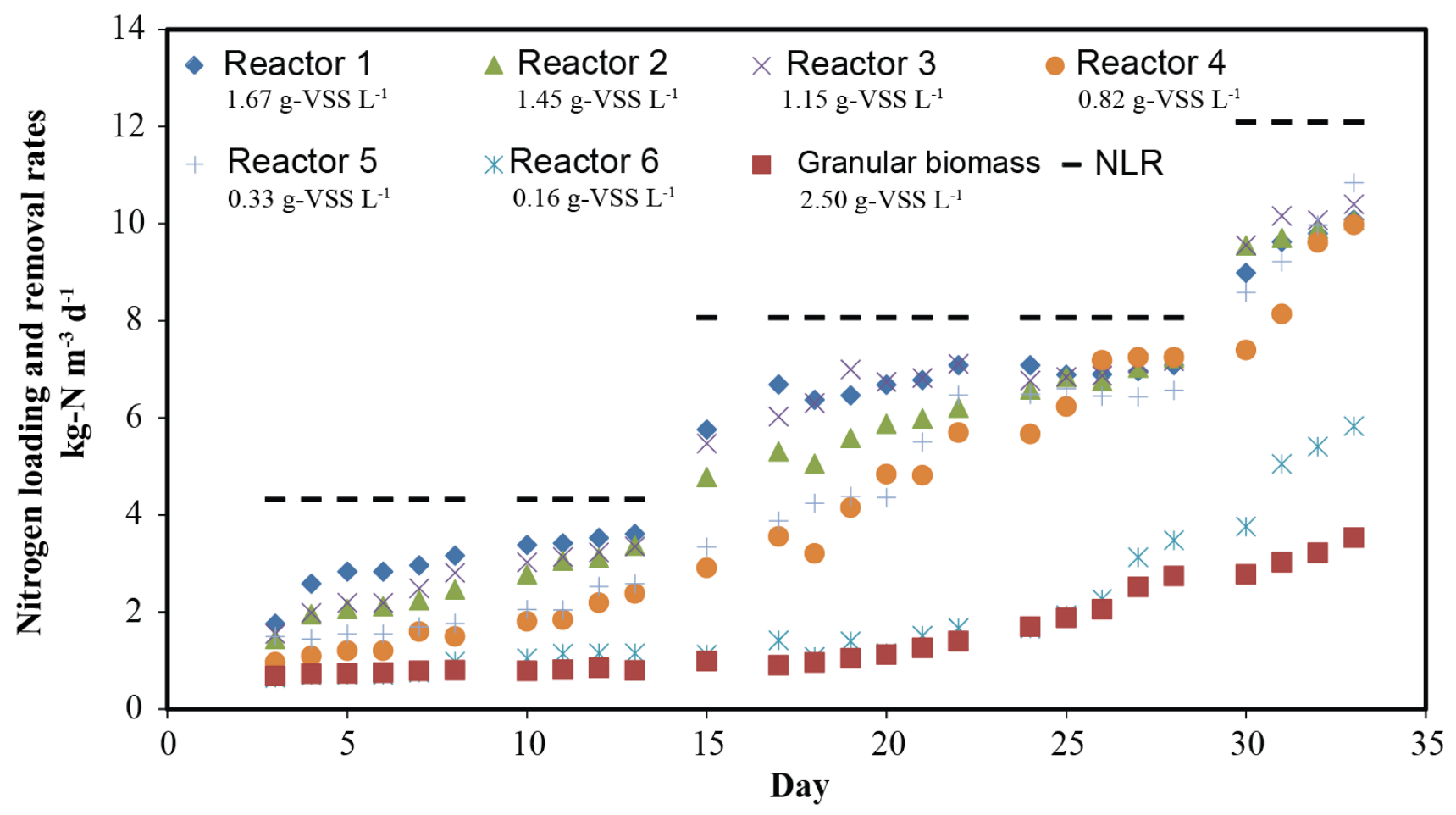

523 Fig. 2. Time courses of nitrogen loading rates (NLRs) and removal rates (NRRs) of six up-flow 524 column reactors containing immobilized anammox biomass and granular biomass. These reactors 525 were operated under the same conditions at $37^{\circ} \mathrm{C}$ for 35 days. 


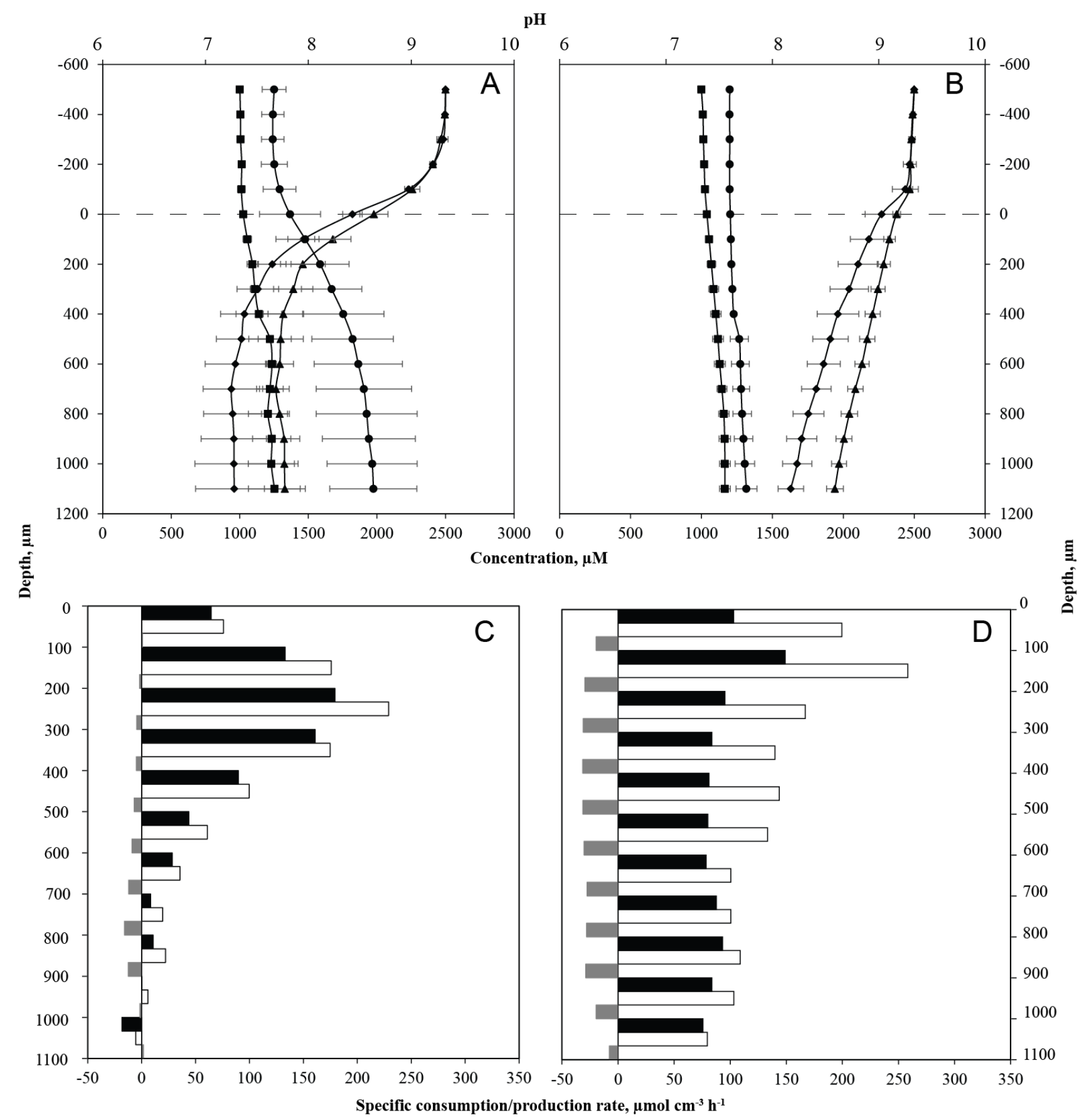

528 Fig. 3. Steady state concentration profiles of ammonium (triangle), nitrite (diamond), nitrate (square) and $\mathrm{pH}$ (circle) in granular biomass (A) and immobilized biomass (B). Dashed line represents a

530 liquid-solid interface of granular or immobilized biomass. These measurements were performed 531 under anoxic condition that was maintained by purging $\mathrm{N}_{2}$ gas. Three profiles were measured for 532 each chemical species using three granules. Error bars indicate the range of standard deviations (SD)

533 derived from triplicate measurements. Spatial distributions of the volumetric consumption and 534 production rates of ammonium (black filled bars), nitrite (empty bars), and nitrate (grey filled bars) 535 of the granular and immobilized biomass are calculated from the average measured concentration 
536 profiles ( $\mathbf{A}$ and $\mathbf{B}$ ) and the newly determined effective diffusion coefficients $\left(D_{e}\right)$ (Table 2 ) using 537 Microsoft EXCEL 2013 add-ins solver, respectively (C and D). Positive and negative values indicate 538 the consumption and production rates, respectively.

539 

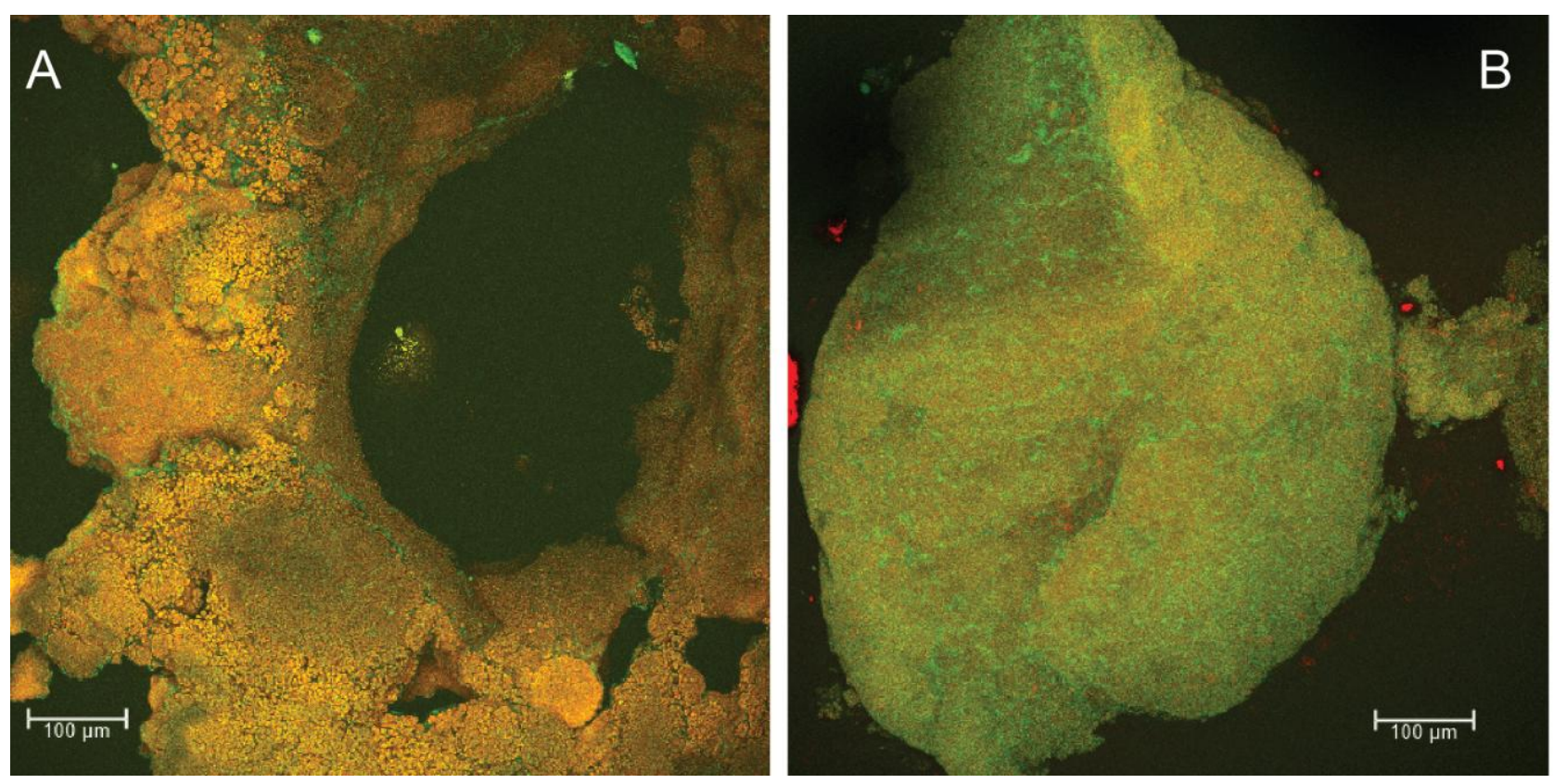

543 Fig. 4. Confocal laser-scanning microscope image of thin cross-section of the granular anammox biomass (A) and immobilized anammox biomass (B), showing in situ spatial organization of anammox bacteria (yellow) and coexisting other bacteria (green). Fluorescence in situ hybridization

546 was performed with FITC-labeled EUB mix probe composed of equimolar EUB338, EUB338II, and 547 EUB338III (green) for most members of Eubacteria and TRITC-labeled amx820 probe (red) for 548 anammox bacteria. Both probes hybridized with anammox bacteria, resulting in yellow signal.

549 Higher abundance of anammox bacteria is detected in the outer layer of the granular biomass, 550 whereas more homogeneous distribution was found in the immobilized biomass. Scale bars represent $551 \quad 100 \mu \mathrm{m}$. 

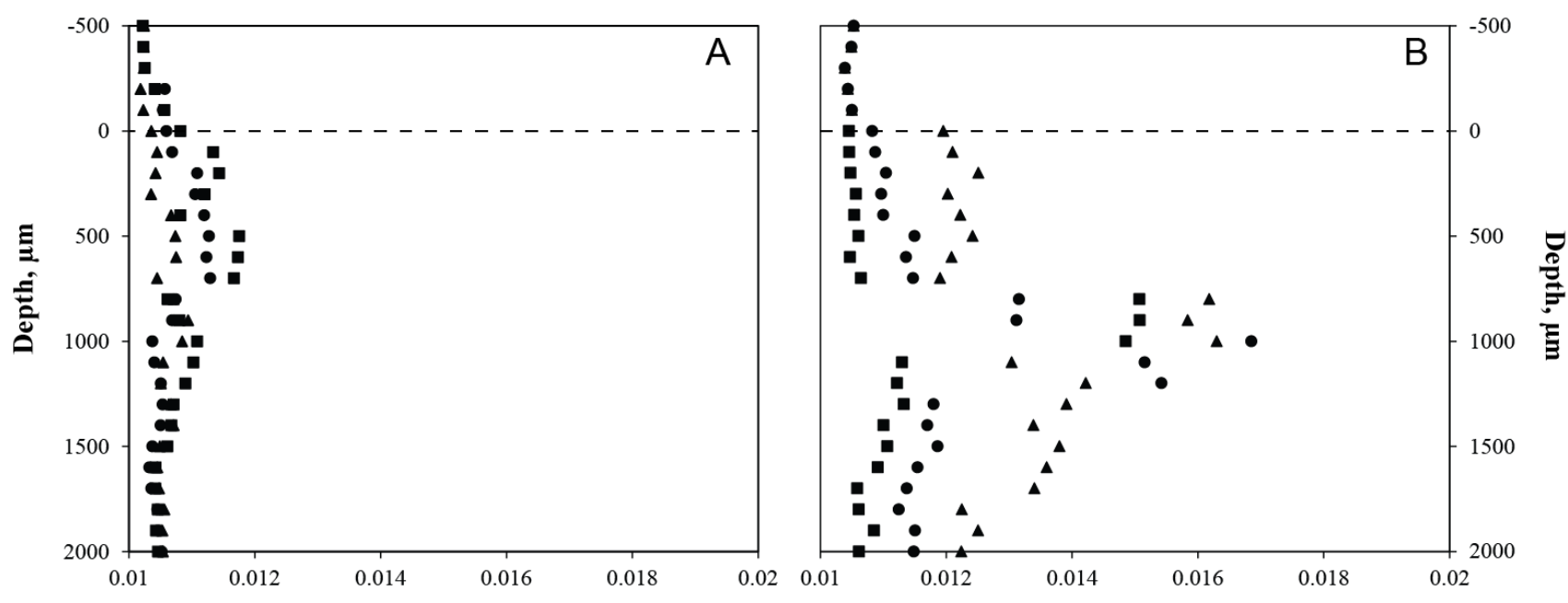

${ }^{13} \mathrm{C} /{ }^{12} \mathrm{C}$

Fig. 5. Carbon isotope ratios $\left({ }^{13} \mathrm{C} /{ }^{12} \mathrm{C}\right)$ of the granular (A) and immobilized biomass $(\mathbf{B})$ analysed by secondary ion mass spectrometry (SIMS) through line profiling technique with a step size of $100 \mu \mathrm{m}$.

558 Dashed lines ( $0 \mu \mathrm{m}$ depth) represent the surface of the granular and immobilized biomass. Positive 559 depths indicate inside of the biofilm. The values of ${ }^{13} \mathrm{C} /{ }^{12} \mathrm{C}$ at negative depths are considered as 560 natural abundance of carbon isotope ratio. In preliminary experiments, adsorption/entrapment of $561{ }^{13} \mathrm{C}$-bicarbonate in gel matrix was not observed for the immobilized biomass. Granular and 562 immobilized biomass were separately inoculated in up-flow column reactor and fed with nutrient 563 medium containing ${ }^{13} \mathrm{C}$-bicarbonate as sole carbon source for 35 days. Triplicate measurements were 564 taken for each type biomass represented by triangle, circle and square. 
PVA-SA gel immobilization is an efficient way to initiate anammox process with less biomass

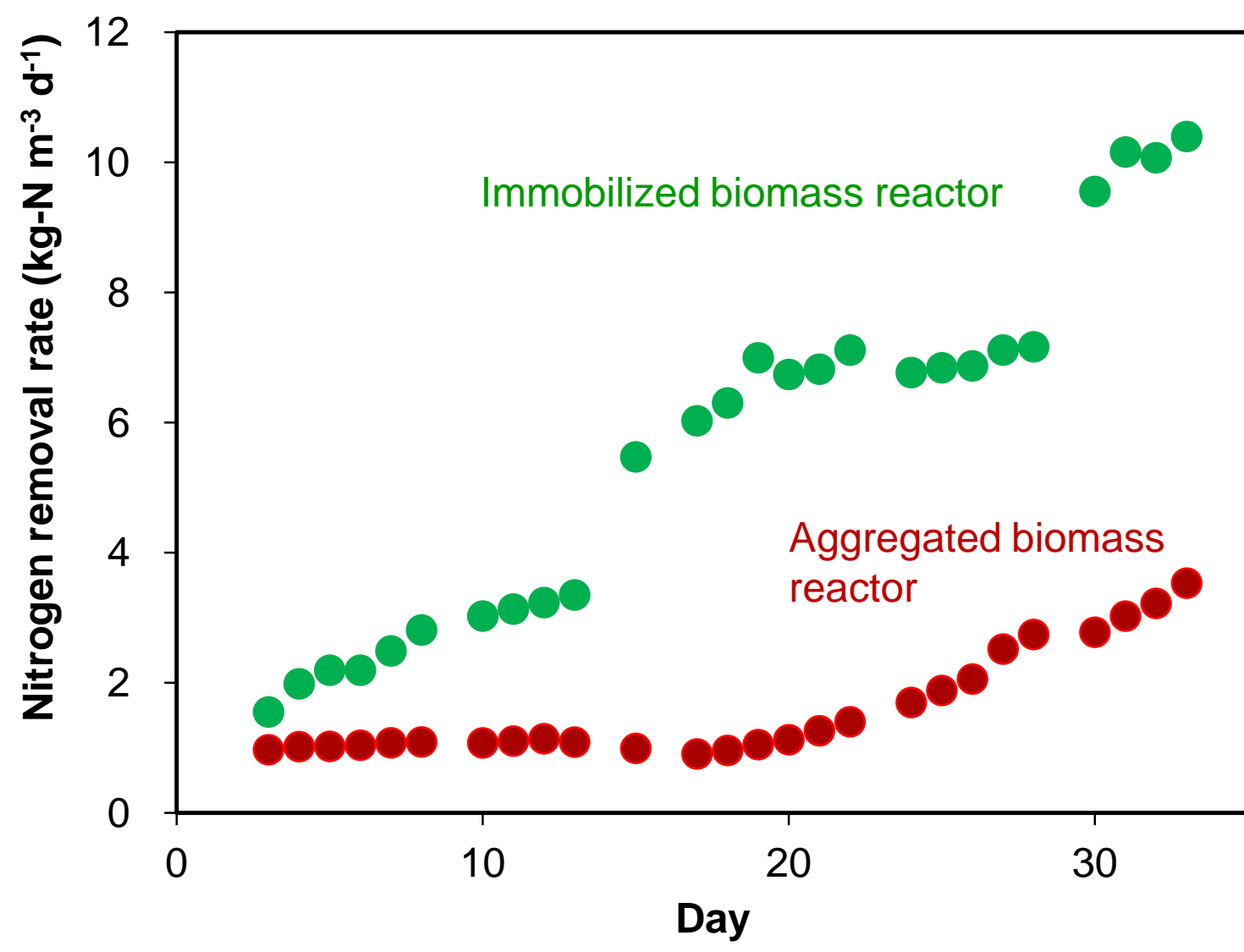

